\title{
DAMPAK PENDIDIKAN AGAMA ISLAM TERHADAP PEMBENTUKAN KEPRIBADIAN ANAK
}

\section{Bahar}

\begin{abstract}
Islamic education is physical and spiritual guidance based on Islamic laws to form main personality according to Islamic standards. In other words, the main personality is the Muslim personality, that is the personality who has Islamic religious values, chooses and decides and acts based on Islamic norms, and is responsible in accordance with Islamic values. The general indicator of an ideal personality of a child is to always pay attention to his/her behavior in worship, traditional behavior, destructive behavior, and constructive behavior. Behavior in worship, for example carrying out prayers perfectly, both in terms of pillars and conditions, doing remembrance and praise of Allah (dhikr) and wirid after prayer, as well as completing the sunnah rawatib prayers. Traditional behavior, for example in ethics of eating, is preceded by praying, eat with the right hand, social and friendly etiquette, travel etiquette, and so on. Destructive behavior, for example avoiding the dangers of lust, the dangers of wealth and being stingy, disdainful and showing off, being arrogant, boasting, cheating, and so on. The constructive behavior, for instance always do self-reflection and selfintrospection, tafakkur,etc.
\end{abstract}

Keywords: Formation, Children's Personality

\section{PENDAHULUAN}

Pendidikan adalah bagian yang tidak terpisahkan dari ajaran Islam secara keseluruhan, ia merupakan bagian yang terpadu dari aspek-aspek ajaran Islam. Karena itulah, dalam sejarah dikatakan bahwa Nabi Muhammad saw sangat mementingkan pendidikan. Beliau senantiasa menempatkan pendidikan sebagai sesuatu yang penting dengan cara mengadakan pengajaran (ta'lìm) kepada para 
21 | MUSAWA, Vol. 13 No.1 Juni 2021 : 20-43

sahabatnya supaya mereka memahami ajaran-ajaran Islam secara universal. ${ }^{1}$ Upaya Nabi Muhammad saw dalam mengajar sahabat-sahabatnya, sebenarnya menjadi misi utamanya. Misi tersebut sesuai yang terdapat dalam ayat yang pertama kali turun "iqra" perintah membaca.

Kebutuhan akan pendidikan, dalam hal ini pendidikan Islam bagi umat Islam setara dengan kebutuhan umat manusia terhadap sandang, pangan, dan papan. Tanpa kegiatan pendidikan, mereka tidak mampu memenuhi eksistensi kemanusiannya sebagai insan paripurna di hadapan Allah swt. Karena itulah, Islam menekankan agar pendidikan dimulai sejak anak baru lahir, sampai di akhir hayatnya. Konsep pendidikan yang demikian, disebut life long education.

Zakiah Daradjat menyatakan bahwa dalam perspektif Islam, pendidikan seumur adalah berlangsung selama hidup dan tujuan akhirnya terdapat pada waktu hidup di dunia ini telah berakhir pula. ${ }^{2}$ Artinya, Islam mengajarkan agar penganutnya dalam mengarungi hidup, dan kehidupannya harus senantiasa terlibat dalam kegiatan belajar untuk pencapaian tujuan pendidikan secara maksimal, yakni pencapaian kepribadian "insan kamil" atau kepribadian yang paripurna.

Kepribadian insan kamil, artinya manusia utuh rohani dan jasmani, dapat hidup dan berkembang secara wajar dan normal karena taqwanya. ${ }^{3}$ Dalam kaitan dengan kepribadian insan kamil, perlu pula dicermati kepribadian manusia secara umum dengan berbagai karakteristiknya. Dalam hal ini, kepribadian manusia sesungguhnya mengandung berbagai sifat hewani dan sifat malaikat.

Sifat hewani, tercermin dalam berbagai kebutuhan fisik yang harus dipenuhinya demi kelangsungan hidupnya. Sedangkan sifat malaikat, adalah salah satu ciri kepribadian insan kamil, di mana dalam kepribadiannya

\footnotetext{
${ }^{1}$ Bahaking Rama, Sejarah Pendidikan Islam: Pertumbuhan dan Perkembangan Hingga Masa Khulafaurrasyidin (Jakarta: Paradotama Wiragemilang, 2002), 5.

${ }^{2}$ Zakiah Daradjat, Ilmu Pendidikan Islam (Cet. III; Jakarta: Bumi Aksara, 1992), 31

${ }^{3}$ Ibid, 29
} 
tercermin kerinduan spiritual untuk mengenal Allah swt, atau dalam konsep sufi disebut ma'rifatullah.

Kadang-kadang antara kedua kepribadian yang disebutkan di atas, terjadi konflik, sehingga kadang-kadang pula manusia tertarik oleh kebutuhankebutuhan dan hawa nafsu fisiknya, dan kadang-kadang tertarik oleh kebutuhan-kebutuhan dan kerinduan spiritualnya. Akibatnya, dalam diri manusia merasakan terjadinya konflik antara kedua aspek kepribadian itu. Dari sini, maka dipahami bahwa dalam diri manusia terdapat kesiapan untuk melakukan kebajikan dan kejahatan, mengikuti hawa nafsu fisiknya tenggelam dalam kenikmatan inderawinya dan berbuat berbagai keinginan duniawinya yang menyimpang dari kepribadian insan kamil. Allah swt berfirman dalam QS. al-Nazi'at (79): 37-41,

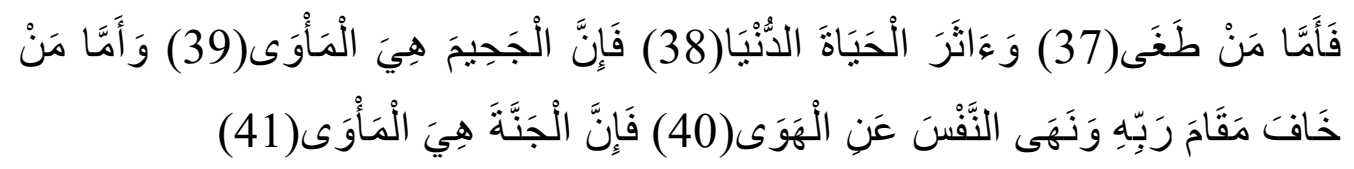

Terjemahnya :

Adapun orang yang melampaui batas, dan lebih mengutamakan kehidupan dunia, maka sesungguhnya nerakalah tempat tinggal (nya). maka sesungguhnya nerakalah tempat tinggal (nya). Dan adapun orang-orang yang takut kepada kebesaran Tuhannya dan menahan diri dari keinginan hawa nafsunya, maka sesungguhnya surgalah tempat tinggal (nya). ${ }^{4}$

Jadi jelaslah bahwa bentuk kepribadian yang diinginkan secara redaksional ayat tersebut, adalah khawf (takut) yang identik dengan takwa, karena takwa secara literal berartu "takut" dan merupakan bentuk pribadi yang

${ }^{4}$ Departemen Agama RI, Al-Qur'an dan Terjemahnya (Jakarta: Proyek Pengadaan Kitab Suci Al-Qur'an, 1992), 1022 
23 | MUSAWA, Vol. 13 No.1 Juni 2021 : 20-43

dapat mengekang hawa nafsunya dari sifat dan sikap negatif yang membahayakan dirinya dan orang lain.

Membicarakan kepribadian, terutama kepribadian anak, oleh kebanyakan pakar menganggapnya sebagai pengaruh yang ditimbulkan anak tersebut atas diri orang lain, dan sebagai pengaruh orang lain, atau lingkungannya. Pembentukan kepribadian anak tersebut, berlangsung secara berangsur-angsur, dan bukanlah hal yang sekali jadi, melainkan sesuatu yang berkembang. Oleh karena itu, pembentukan kepribadian merupakan suatu proses. Akhir dari perkembangan itu, kalau berlangsung dengan baik, akan menghasilkan suatu kepribadian yang harmonis. Selanjutnya, kepribadian itu disebut harmonis kalau segala aspek-aspeknya seimbang, kalau tenaga-tenaga bekerja simbang pula sesuai dengan kebutuhan. Pada segi lain, kepribadian yang harmonis dapat dikenal, pada adanya keseimbangan antara peranan individu dengan pengaruh lingkungan sekitarnya. ${ }^{5}$

Lingkungan mempunyai peranan yang sangat penting terhadap keberhasilan pendidikan, karena perkembangan seseorang sangat dipengaruhi oleh lingkungannya. Ramayulis menyatakan, lingkungan dapat memberikan pengaruh yang positif dan pengaruh yang negatif terhadap pertumbuhan dan perkembangan kepribadian anak, yakni sikap, akhlak dan perasaan agama. ${ }^{6}$

Antara lain lingkungan yang memiliki peran penting dalam mempengaruhi kepribadian anak, adalah lingkungan sekolah. Lingkungan ini, disebut pula lingkungan pendidikan formal. ${ }^{7}$ Dalam upaya pembentukan kepribadian anak yang dicita-citakan, maka pendidikan melalui sistem persekolahan patut diberikan penekanan yang istimewa, karena pendidikan

${ }^{5}$ Ahmad D. Marimba, Pengantar Filsafat Pendidikan Islam (Cet. VIII: Bandung: PT. AlMa'arif, 1989), 75

${ }^{6}$ Ramayulis, Ilmu Pendidikan Islam (Cet. I; Jakarta: Kalam Mulia, 1994), 146

${ }^{7}$ Tentang pendidikan formal, lihat Republik Indonesia, Undang-Undang RI No. 20 tahun 2003 tentang Sistem Pendidikan Nasional (Cet. I; Bandung: Fokusmedia, 2003), 6 
sekolah mempunyai program yang teratur, bertingkat dan mengikuti syarat yang jelas dan ketat.

\section{METODE PENELITIAN}

Penelitian ini adalah penelitian kualitatif yang bersifat studi pustaka (library research) yang menggunkan buku-buku dan literatur-literatur lainnya sebagai objek yang utam.Jenis penelitian yang digunakan adalah kualitatif, yaitu penelitian yang menghasilkan informasi berupa catatan dan data deskriptif yang terdapat di dalam teks yang diteliti.

\section{TINJAUAN PUSTAKA}

\section{A. Pengertian Kepribadian}

Dari telaahan kepustakaan yang dilakukan, ditemukan bahwa term kepribadian dalam beberapa bahasa disebut dengan personality (Inggris); persoonlijkheid (Belanda); personnalita (Prancis); personalita (Itali); personlichkeit (Jerman); dan personalidad (Spayol). ${ }^{8}$ Abd. Mujib menjelaskan bahwa dari term-term kepribadian dalam berbagai bahasa, pada dasarnya masingmasing sebutan itu berasal dari kata latin, yakni persona yang berarti topeng. ${ }^{9}$ Topeng adalah tutup muka yang sering dipakai oleh pemain-pemain panggung yang maksudnya untuk meng-gambarkan perilaku, watak atau pribadi seseorang. Misalnya, untuk mengidentikkan kepribadian yang angkara murka, serakah, dan hebat, sering ditopengkan dengan gambar raksasa. Sedang untuk perilaku yang baik, budiluhur, suka menolong, berani berkorban, ditopengkan dengan seorang

${ }^{8}$ Agus Sujanto, dkk, Psikologi Kepribadian (Cet. VII; Jakarta: Bumi Aksara, 1997), h. 10. Lihat juga Simpson, D.P., Cassell's Latin Dictionary (New York: Mac Millan Publishing Co, 1982), 442.

${ }^{9}$ Abdul Mujib, Fitrah dan Kepribadian Islam; Sebuah Pendekatan Psikologis (Cet.I; Jakarta: Darul Falah, 1999), 72. 
25 | MUSAWA, Vol. 13 No.1 Juni 2021 : 20-43

ksatria. Dengan demikian, kepribadian yang digambarkan oleh sebuah topeng menunjukkan suatu kualitas prilaku dominan seseorang. Bilamana dalam keseharian seseorang prilakunya dominan baik, kepribadiannya baik pula.

Dalam konsep ajaran Islam, kepribadian yang baik, adalah sosok kepribadian muslim yang ideal. Kepribadian yang demikian, dalam kamus (almunjid) bahasa Arab disebut syakhsiyah al-barizah. ${ }^{10}$ Kata syakhsiyah ini, berakar dari kata syakhs artinya pribadi. Kata tersebut kemudian diberi ya nisbat, menjadi kata benda buatan (mashdar shinaiy).

Selanjutnya batasan kepribadian secara terminologi, ditemukan pula keragaman definisi yang dikemukakan masing-masing pakar sesuai bidangnya. Sigmund Freud sebagai bapak psikoanalisis mendefiniskan kepribadian sebagai integrasi dari id, ego, dan super ego. ${ }^{11}$ Id sebagai komponen kepribadian psikologis, ego sebagai komponen kepribadian psikologis, dan super ego sebagai komponen kepribadian sosiologis. Ketiga sistem ini, tidak dipandang sebagai elemen-elemen yang terpisah-pisah, melainkan suatu nama untuk berbagai proses psikologis yang mengikuti prinsip-prinsip sistem yang berbeda. Dengan demikian, definisi yang dikemukakan Sigmund Freud menekankan kekuatan aktif dalam diri individu dan tidak menekankan pada kebiasaan-kebiasaan seseorang. Kekuataan yang dimaksud berupa organisasi sistem-sistem psikis yang secara integratif bekerja sama untuk mencapai tingkah laku tertentu.

Selanjutnya Alfred Adler tokoh psikososial mendefinisikan kepribadian sebagai gaya hidup individu, atau cara yang karakteristik mereaksinya seseorang terhadap masalah-masalah hidup, termasuk tujuan hidup. ${ }^{12}$ Definisi ini menggambarkan bahwa setiap individu memiliki konsep diri seseungguhnya dan konsep diri ideal. Konsep diri sesungguhnya adalah konsep seseorang dari siapa

\footnotetext{
${ }^{10}$ M. Napis Djueni, Kamus Kontemporer Istilah Politik-Ekonomi Indonesia Arab (Cet. I; Bandung: Teraju, 2005), 218

${ }^{11}$ Batasan Sigmund Freud tentang kepribadian, dapat dilihat dalam C.P. Chaplin, Dictionary of Personality diterjemahkan oleh Kartini Kartono dengan judul Kamus Lengkap Psikologi (Jakarta: Rajawali, 1989), 362

${ }^{12}$ Ibid.
} 
dan apa dia itu. Konsep ini merupakan bayangan cermin yang ditentukan oleh peran dan hubungannya dengan orang lain dan apa yang kiranya reaksi orang lain terhadapnya. Sedangkan konsep diri ideal adalah gambaran seseorang mengenai penampilan dan tingkah laku. Kedua konsep inilah yang menjadi komponen terpenting dalam melihat kepribadian seseorang.

Sebagai tokoh psikososial, Alfred Adler mengkaitkan definisinya dengan masalah-masalah kehidupan sosial. Jadi semakin tinggi tingkat interaksi sosial seseorang, semakin tinggi pula tingkat kualitas kepribadiannya. Dalam aspek ini, dipahami bahwa kepribadian merupakan hasil interaksi diri seseorang dengan lingkungannya. Hal ini sejalan dengan definisi kepribadian yang dikemukakan G.W. Allport, yakni :

Personality is the dynamic organization within the individual of those psychophysical system, that determines his uinique adjusment to his environment. ${ }^{13}$ Kepribadian itu adalah suatu organisasi psichophysis yang dinamis daripada seseorang yang menyebabkan dia dapat menentukan penyesuaian dirinya yang khas dengan lingkungannya.

Definisi di atas, memiliki lima prinsip pokok kepribadian, yaitu :

1. Organisasi dinamis, artinya kepribadian selalu berkembang dan berubah, meskipun terdapat organisasi atau sistem-sistem psikofisik yang mengikat dan menghubungkan berbagai komponen dari kepribadian.

2. Psikofisik (psichophysis), artinya kepribadian bukanlah semata-mata kerja mental belaka tanpa melibatkan neural. Istilah organisasi mengisyaratkan beroprasinya badan dan jiwa, berpadu secara tidak terputuskan menjadi kesatuan pribadi.

${ }^{13}$ G.W. Alfort dikutip dari Calvin Hal dan Lindzey Gardner, Theories of Personality, diterjemahkan oleh Yustinus dengan judul Teori-teori Holistik Organismik-Fenomenologis (yogyakarta: Kanisius, 1993), 24. 
27 | MUSAWA, Vol. 13 No.1 Juni 2021 : 20-43

3. Menentukan, artinya kepribadian terdiri atas kecenderungan-kecenderungan individu. Kepribadian adalah sesuatu yang berbuat sesuatu. Kepribadian adalah apa yang terletak dibalik perbuatan-perbuatan khusus dan di dalam individu.

4. Khas, artinya individualitas individu, sebab tidak ada dua orang yang benarbenar memiliki kepribadian yang sama, walaupun dari anak kembar.

5. Menyesuaikan diri dengan lingkungan, artinya kepribadian menjadi jembatan individu dengan lingkungan psik dan lingkungan psikologisnya. Kepribadian di sini merupakan sesuatu yang mempunyai fungsi atau arti, adaptasi dan menentukan.

Definisi di atas dan gambaran prinsip kepribadian di dalamnya, sejalan juga dengan empat definisi yang dikemukakan oleh Sarlito Wirawan Sarwono yang telah penulis kutip dalam bab I skripsi ini. Ringkasnya, kepribadian yang dirumuskan oleh masing-masing pakar memiliki beberapa aspek kesamaan, terutama yang bertumpuh pada bagian dari individu yang paling mencerminkan atau mewakili sang pribadi.

Berdasar pada definisi-definisi kepribadian sebelumnya, dapat dirumuskan bahwa terdapat dua kata kunci mengenai kepribadian, yakni "sifat" dan "sikap" yang ada pada setiap individu dan tercermin dalam prilakunya sehari-hari. Dengan demikian, penulis merumuskan bahwa kepribadian adalah organisasi psiko dan fisik yang dinamis dan tergambar dalam diri setiap individu yang masing-masing berbeda dengan individu lainnya dalam menentukan penyesuaian dirinya masingmasing terhadap lingkungannya.

\section{B. Faktor-faktor Yang Mempengaruhi Kepribadian}

Kepribadian manusia secara umum, dan termasuk di dalamnya tentang kepribadian anak secara khusus, telah mendapat perhatian dari kalangan pakar psikologi dan pendidikan dengan berbagai alirannya. Studi mereka lebih berfokus pada faktor-faktor yang menentukan kepribadian. Terdapat tiga aliran besar yang masing-masing memiliki asumsi berbeda dalam melihat faktor-faktor yang 
mempengaruhi kepribadian. Tiga aliran tersebut adalah nativisme, empirisme, dan konvergensi.

\section{Aliran Nativisme}

Nativisme berasal dari kata natus = lahir; nativis = pembawaan yang ajarannya memandang manusia (anak manusia) sejak lahir telah membawa sesuatu kekuatan yang disebut potensi (dasar). ${ }^{14}$ Aliran nativisme ini, bertolak dari leibnitzian tradition yang menekankan kemampuan dalam diri setiap pribadi, sehingga faktor lingkungan, termasuk faktor pendidikan, kurang berpengaruh terhadap kepribadian. Dengan kata lain bahwa aliran nativisme berpandangan segala sesuatunya ditentukan oleh faktor-faktor yang dibawa sejak lahir, jadi perkembangan individu itu semata-mata dimungkinkan dan ditentukan oleh dasar turunan, misalnya; kalau orangtuanya berkepribadian ideal, kemungkinan besar anaknya juga berkepribadian ideal.

Aliran nativisme memandang hereditas (heredity) sebagai penentu kepribadian. Hereditas adalah totalitas sifat-sifat karakteristik yang dibawah atau dipindahkan dari orang tua ke anak keturunannya. Perpindahan genetik ini merupakan fungsi dari kromosom dan gen. Kromoson adalah bagian sel yang mengandung sifat keturunan, satu tubuh yang berwarna gelap di dalam inti sel elementer. Gen adalah sebarang partikel hipotetik yang terletak sepanjang kromoson-kromoson yang menjadi unit elementer dari sifat keturunan atau kebakaan. $^{15}$

Asumsi yang mendasari aliran nativisme ini, adalah bahwa pada kepribadian anak dan orang tua terdapat banyak kesamaan, baik dalam aspek fisik dan psikis. Setiap manusia memiliki gen, dan gen orangtua ini yang berpindah pada anak. Dengan begitu, para penganut aliran nativisme berpandangan bahwa bayi itu lahir sudah dengan pembawaan baik dan pembawaan buruk berdasarkan

\footnotetext{
${ }^{14}$ Sumadi Suryabrata, Psikologi Perkembangan (Yogyakarta: Rake Press, 1984), 85

${ }^{15}$ Mohammad Nur Syam, Filsafat Pendidikan (Surabaya: Usaha Nasional, 1986), 299
} 
29 | MUSAWA, Vol. 13 No.1 Juni 2021 : 20-43

gen orangtuanya. Sehingga, kepribadian ditentukan oleh pembawaan yang sudah dibawa sejak lahir. ${ }^{16}$ Berdasarkan pandangan ini, maka baik dan buruknya kepribadian seseorang ditentukan oleh pembawaan.

Bagi nativisme, lingkungan sekitar tidak ada artinya sebab lingkungan tidak akan berdaya dalam mempengaruhi kepribadian seseorang. Penganut pandangan ini menyatakan bahwa kalu anak mempunyai pembawaan kepribadiaan jahat, dia akan menjadi jahat, sebaliknya kalau anak mempunyai pembawaan kepribadian baik, dia menjadi orang yang baik. Kepribadian buruk dan baik ini tidak dapat dirubah oleh kekuatan lingkungan.

Berkenaan dengan inti ajaran aliran nativisme, dapat dipahami bahwa aliran ini bersifat passimisme, karena para penganutnya menunjukkan sifat pesimistis terhadap kemampuan manusia dalam mengembangkan kepribadiannya yang dibawa sejak lahir. Dengan kata lain, kepribadian anak seluruhnya ditentukan oleh hukum-hukum pewarisan. Dengan demikian, dipahami bahwa aliran nativisme pada dasarnya terlepas dari konsep fitrah karena melepaskan diri dari ikatan agama yang transedental. Manusia menurut aliran ini seakan-akan mentuhankan orantua dan nenekmoyang, sebab dialah sumber utama pewarisan kepribadian.

\section{Empirisme}

Aliran empirisme, bertentangan dengan paham aliran nativisme. Empirisme (empiri artinya, pengalaman), dan disebut juga aliran environmentalisme, yaitu suatu aliran yang menitikberatkan pandangan-nya pada peranan lingkungan sebagai penyebab timbulnya kepribadian. ${ }^{17}$ Aliran ini tidak mengakui adanya pembawaan atau potensi kepribadian yang di bawah manusia sejak kelahirannya. Dengan kata lain bahwa anak manusia itu lahir dalam keadaan suci dalam pengertian anak bersih tidak membawa apa-apa. Karena itu, aliran ini

\footnotetext{
${ }^{16}$ Umar Tirharahardja dan La Sula, Pengantar Pendidikan (Cet. II; Jakarta: Rineka Cipta, 1996), 196

${ }^{17}$ Syam, Filsafat, 41
} 
Bahar, Dampak Pendidikan Agama Islam ... | 30

berpandangan bahwa kepribadian seseorang besar pengaruhnya pada faktor lingkungan.

Asumsi psikologis yang mendasari aliran empirisme ini, adalah bahwa manusia lahir dalam keadaan netral, tidak memiliki pembawaan kepribadian. Ia bagaikan kertas putih (tabula rasa) yang dapat ditulisi apa saja yang dikehendaki. Perwujudan kepribadian ditentukan oleh luar diri yang disebut lingkungan, dengan kiat-kiat rekayasa yang bersifat edukatif.

Dapat diilustrasikan bahwa setiap bayi, menangis bila merasa lapar, haus, dan sakit yang berarti bahwa bayi tersebut dalam keadaan kosong yang memerlukan bantuan, dan kemudian kepribadian menjadi tumbuh dan berkembang disebabkan oleh pengaruh lingkungan dalam proses kehidupannya. Muhammad Mahmud menyatakan bahwa lingkungan yang mempengaruhi kepribadian terdiri atas lima faktor, yaitu geografis, historis, sosiologis, kultural, dan psikologis. ${ }^{18}$

Lingkungan geografis disebut juga lingkungan alamiah, yaitu lingkungan yang ditentukan oleh letak wilayah dan kondisi iklim. Letak wilayah seperti di dataran, pegunungan dan pesisir pantai. Kondisi iklim seperti panas, tropik, sedang, dan salju. Lingkungan historis, yaitu lingkungan yang ditentukan oleh ciri suatu masa atau era dengan segala perkembangan peradabannya. Dalam konteks keIndionesiaan, era orde lama, orde baru, dan era reformasi tanpak memiliki perbedaan. Masing-masing era memiliki corak dan kondisi tersendiri. Lingkungan sosiologis, yaitu lingkungan yang ditentukan oleh hubungan antar individu dalam suatu komunitas sosial. Hubungan ini selalu dikaitkan dengan tradisi, dan adat kebiasaan. Lingkungan kultural, yaitu lingkungan yang ditentukan oleh kultur masyarakat. Kultur ini meliputi cara berpikir, bertindak, ber-perasaan, dan sebagainya. Lingkungan psikologis, yaitu lingkungan yang ditentukan oleh

\footnotetext{
${ }^{18}$ Muhammad Mahmud, 'Ilm al-Nafs al-Ma'āsir fì Daw'i al-Islām (Jeddah: Dār al-Syurūq, 1984), $117-120$
} 
31 | MUSAWA, Vol. 13 No.1 Juni 2021 : 20-43

konidisi kejiwaan, seperti kondisi rasa aman, keamanan, toleransi, dan sebagainya.

Masing-masing lingkungan di atas merupakan faktor penyebab yang menentukan kepribadian seseorang, walaupun proporsinya tidak seimbang. Suatu kepribadian kadang-kadang lebih di dominasi oleh faktor lingkungan tertentu dan memperkecil proporsi faktor lingkungan lain. Ketika faktor lingkungan ini berfungsi pada diri seseorang, maka kepribadiannya akan terpengaruh.

Bilamana aliran nativisme disebut aliran pasimesme, maka aliran empirisme ini dapat disebut sebaga aliran optimisme. Sebab, inti ajarannya adalah menganggap kepribadian menjadi akan lebih lain apabila dirangsang oleh usahausaha sekuat tenaga. Kepribadian manusia bukanlah sebuah robot yang diprogram secara deterministik, apalagi menyerah pada pembawaan nasibnya. Dengan aliran empirisme ini telah menyumbangkan pemikiran tentang bagaimana manusia agar segara membentuk kepribadiannya yang ideal.

Menurut Redja Mudyahardjo bahwa aliran nativisme ini berpandangan behavioral, karena menjadikan perilaku manusia yang tampak keluar sebagai sasaran kajiannya, dengan tetap menekankan bahwa perilaku dan kepribadian ditentukan oleh faktor ekstern semata-mata. ${ }^{19}$ Dengan demikian dapat dipahami baik dan atau buruknya suatu kepribadian menurut aliran empirisme ini, adalah ditentukan sepenuhnya oleh lingkungan sekitar.

\section{Aliran Konvergensi}

Aliran konvergensi berasal dari kata konvergen, artinya bersifat menuju satu titik pertemuan. Aliran ini berpandangan bahwa corak kepribadian ditentukan oleh dasar (bakat, keturunan) dan lingkungan, kedua-duanya memainkan peranan penting. Konvergensi sebagai satu aliran teori, menekankan adanya hubungan antara faktor pembawaan sejak lahir dan faktor pengalaman yang diperoleh dari

\footnotetext{
${ }^{19}$ Redja Mudyahardjo, Pengantar Pendidikan; Sebuah Studi Awal tentang Dasar-dasar Pendidikan pada Umumnya dan Pendidikan di Indonesia (cet. II; Jakarta: PT. RajaGrafindo Persada, 2002), 152
} 
lingkungan sekitarnya. Itu berarti bahwa aliran komvergensi ini, mempertemukan teori nativisme dan empirisme.

Manusia secara pribadi telah memiliki bakat masing-masing yang dibawanya sejak lahir (fitrah), yang kemudian karena pengaruh lingkungan yang sesuai dengan kebutuhan bakat tadi akan mengalami perkembangan. Akan tetapi bakat saka tanpa pengaruh lingkungan yang sesuai dengan kebutuhan perkembangan tersebut, tidak cukup, misalnya tiap anak manusia yang normal mempunyai bakat untuk berdiri di atas kedua kakinya, akan tetapi bakat sebagai kemungkinan ini tidak akan menjadi aktual (menjadi kenyataan), jika sekiranya anak manusia itu tidak hidup dalam lingkungan masyarakat manusia. Dengan begitu, hereditas tidak akan berkembang secara wajar apabila tidak diberi rangsangan dari faktor lingkungan. Sebaliknya, rangsangan lingkungan tidak akan membina kepribadian yang ideal tanpa didasari oleh faktor hereditas. Ringkasnya, penentuan kepribadian seseorang dipengaruhi oleh kerja yang integral antara faktor internal dan eksternal.

Jadi inti aliran konvergensi ini, adalah bahwa kepribadian seseorang tidak hanya ditentukan oleh faktor warisan saja, dan tidak juga ditentukan oleh faktor lingkungan. Kepribadian seseorang akan ditentukan oleh hasil perpaduan antara kedua faktor tersebut, hasil kerjasama antara faktor-faktor yang ada pada diri seseorang, dan faktor-faktor di luarnya akan bermuara suatu pribadi yang ideal.

Sejalan dengan itu, Nasir Budiman menyatakan bahwa manusia dengan segala perwatakan dan ciri-ciri pertumbuhannya adalah perwujudan dua faktor, yaitu faktor warisan dan lingkungan. Kedua faktor ini mempengaruhi manusia dan berintegrasi denganya sejak hari pertama kelahirannya sampai akhir hayatnya. ${ }^{20}$ Berdasarkan pada uraian-uraian di atas, kelihatan bahwa konsep kepribadian perspektif Islam akan lebih dekat pada aliran kovergensi yang tidak

\footnotetext{
${ }^{20}$ M. Nasir Budiman, Pendidikan dalam Perspektif Al-Qur'an (Cet.I; JakartaL Madani Press, 2001), 49
} 
33 | MUSAWA, Vol. 13 No.1 Juni 2021 : 20-43

mengabaikan konsep fitrah, walaupun tidak sama karena perbedaan paradigmanya. Adapun kedekatannya, adalah bahwa Islam menegaskan kepribadian manusia memiliki fitrah dan sumber daya insani, serta bakat-bakat bawaan, meskipun semua itu masih merupakan potensi yang mengandung berbagai kemungkinan, seperti yang dijelaskan oleh al-Taumiy :

Betapapun juga, faktor keturunan tidaklah merupakan suatu yang kaku hingga tidak bisa dipengaruhi. Bahkan ia bisa dilenturkan dalam batas tertentu. Alat untuk melentur dan mengubahnya ialah lingkungan dengan segala anasirnya. Lingkungan sekitar ialah aspek pendidikan yang penting. ${ }^{21}$

Ditegaskan pula dalam sebuah hadis ;

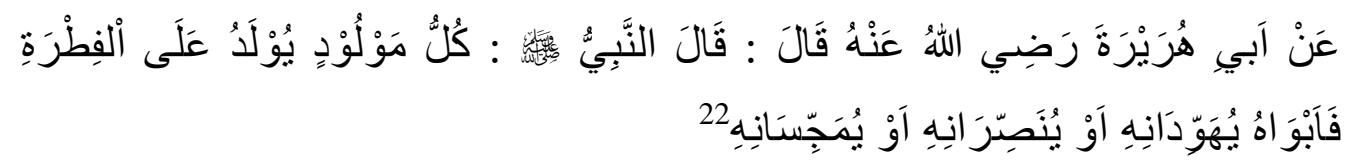

Artinya:

'Dari Abi Hurairah ra, bahwa Nabi saw. bersabda: setiap anak yang lahir, dilahirkan dalam keadaan fitrah, maka orang tualah yang menjadikan ia Yahudi, Nasrani atau Majusi’. (HR. Muslim)

Konsep fitrah dalam hadis di atas, mengandung arti potensi dasar yang dibawa oleh setiap manusia sejak lahir. Potensi ini adalah kepribadian Islam, namun potensi kepribadian tersebut kadangkala tidak bisa berkembang karena keadaan lingkungan yang tidak mendukung. Seorang anak memungkinkan saja berkepribadian Yahudi atau Nasrani bila tidak ada usaha orangtua (lingkungan) yang mengarahkannya.

21 'Umar Muhammad al-Taumiy al-Syabāni, Falsafat al-Tarbiyat al-Islāmiyah, diterjemahkan oleh Hasan Langgulung dengan judul Falsafah Pendidikan Islam (Cet. I; Jakarta: Bulan Bintang, 1979), 138

${ }^{22}$ Imām Ibn Husain Muslim bin Hajjāj Ibn Muslim al-Qusyairi al-Naisabūri, al-Jāmi Sahīh, Juz VI (Bairut: Dār al-Ma'ārif, t.th.), 530. 
Bahar, Dampak Pendidikan Agama Islam ... | 34

Dapat dirumuskan bahwa Islam mengakui faktor keturunan (bakat, pembawaan) dan faktor lingkungan (pengalaman) sebagai penentu baik dan buruknya kepribadian. Akan tetapi di samping kedua faktor tersebut masih ada lagi faktor lain yang cukup berpengaruh, yaitu hidaya Allah swt. Bahkan faktor hidayah ini sering lebih dominan dalam menentukan sosok kepribadian. Seorang anak, yang sudah terbiasa beraklak buruk sejak kecil, tidak menunaikan kewajiban agama, namun pada suatu saat, setelah ia mendapat hidayah Allah swt, ia menjadi anak shaleh dan sangat tampak dalam perilakunya, akhlak al-mahmudah.

\section{HASIL DAN PEMBAHASAN}

\section{A. Konsep Kepribadian Anak yang Dicita-citakan Pendidikan Agama Islam}

Konsep kepribadian anak yang yang dicita-citakan PAI, dapat dilihat dari tujuan pendidikan Islan itu sendiri. Zakiah Daradjat menyebutkan empat, yakni tujuan umum, tujuan akhir, tujuan sementara, dan tujuan operasional. ${ }^{23}$ Mappanganro menyebutkan adanya tujuan umum, tujuan institusional, tujuan kurikuler, tujuan instruksional umum, dan tujuan instruksional khusus. ${ }^{24}$

Berkenaan dengan tujuan-tujuan pendidikan Islam tersebut, penulis melihatnya dengan cara katergorisasi. Dalam hal ini, tujuan pendidikan Islam, bila dilihat dari kategori gradasinya, ada tujuan akhir dan tujuan sementara. Dilihat dari kategori sifatnya, ada tujuan umum dan tujuan khusus. Dilihat dari kategori orientasi output-nya, ada tujuan individual dan tujuan sosial. Dilihat dari kategori penyelenggaraannya secara formal, ada tujuan instruksional, tujuan kurikuler,

${ }^{23}$ Zakiah Daradjat, Ilmu Pendidikan Islam (Cet. III; Jakarta: Bumi Aksara, 1996), 30-32

${ }^{24}$ Mappanganro, Impelementasi Pendidikan Islam di Sekolah (Cet. I; Ujung pandang: Ahkam, 1996), 29. 
35 | MUSAWA, Vol. 13 No.1 Juni 2021 : 20-43

tujuan institusional, dan tujuan nasional. Kategorisasi tujuan-tujuan tersebut menunjuk kepada proses, dan pendidikan Islam adalah usaha yang berproses. Sehingga secara garis besarnya, semua tujuan-tujuan tadi dapat dirinci menjadi tujuan sementara dan tujuan akhir.

Tujuan sementara merupakan penjabaran dari tujuan akhir, serta berfungsi membantu memelihara arah seluruh usaha, dan menjadi wahana untuk mencapai tujuan akhir pendidikan Islam, yakni pembentukan kepribadian muslim ideal yang identik dengan kepribadian insan kamil. Untuk menegaskan bahwa kepribadian muslim atau kepribadian insan kamil adalah memang benar-benar menjadi tujuan akhir dari pendidikan Islam, dapat dikutip beberapa konsep yang dikemukakan para pakar pendidikan Islam, yakni :

1. Ahmad D. Marimba :

Pendidikan Islam, yaitu bimbingan jasmani dan rohani berdasarkan hukum-hukum agama Islam menuju terbentuknya kepribadian utama menurut ukuran-ukuran Islam. Dengan pengertian lain kepribadian utama adalah kepribadian muslim, yaitu kepribadian yang memiliki nilai-nilai agama Islam, memilih, dan memutuskan serta berbuat berdasarkan nila-nilai Islam, dan bertanggungjawab sesuai dengan nilainilai Islam. ${ }^{25}$

2. Achmadi :

Pendidikan Islam ialah segala usaha untuk memelihata dan mengembangkan fitrah manusia menuju terbentuknya manusia seutuhnya (insan kamil) sesuai dengan norma Islam. Konsep manusia seutuhnya dalam pandangan Islam dapat di formulasikan secara garis besar sebagai pribadi muslim, yakni manusia yang beriman dan bertaqwa serta memiliki berbagai kemampuan yang teraktualisasi dalam

${ }^{25}$ Ahmad. D. Marimba, Filsafat Pendidikan Islam (Bandung: PT. Al-Ma'arif, 1980), 2324. 
Bahar, Dampak Pendidikan Agama Islam ... |36

hubungannya dengan Tuhan, sesama manusia dan lingkungan alam sekitarnya secara baik, positif dan konstruktif. ${ }^{26}$

3. Abu Ahmadi dan Nur Uhbiyati :

Pendidikan Islam ialah suatu aktifitas/usaha pendidikan terhadap anak didik menuju ke arah terbentuknya kepribadian muslim yang muttaqiem [muttaqin]. ${ }^{27}$

Konsep-konsep pendidikan Islam yang dikutip di atas, secara jelas di dalamnya termuat "kepribadian muslim" sebagai tujuan pendidikan Islam, dan inilah yang menjadi tujuan yang dicita-citakan pendidikan Islam.

Adapun Tujuan pendidikan menurut Islam adalah membentuk seorang muslim yang mampu melaksanakan kewajibannya kepada Allah Swt. ${ }^{28}$ Selain itu, Ahmad D. Marimba mengkonsepsikan kepribadian muslim sebagai kepribadian utama menurut ukuran-ukuran Islam. Achmadi mengkonsepsikan kepribadian muslim sebagai manusia seutuhnya yang identik dengan insan kamil, dan pribadi manusia yang beriman dan bertaqwa. Nur Uhbiyati mengkonsepsikan kepribadian muslim sebagai orang yang muttaqin. Dengan demikian, kepribadian muslim sebagai tujuan akhir yang ingin dicapai dalam pendidikan Islam adalah perwujudan sosok insan kamil dengan pola iman, dan takwa. Tujuan akhir pendidikan Islam seperti ini, dipahami dalam firman Allah swt., QS. Ali Imran (3): 102,

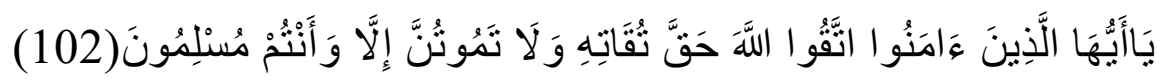

\footnotetext{
${ }^{26}$ Achmadi Ideologi Pendidikan Islam; Paradigma Humanisme Teosentris (Cet.I; Yogyakarta: Pustaka Pelajar, 2005), 29.

${ }^{27}$ Abu Ahmadi dan Nur Uhbiyati, Ilmu Pendidikan (Cet. I; Jakarta: Rineka cipta, 1991), 111.

${ }^{28}$ M. Iksan Kahar, Pendidikan Karakter pada Anak Usia Dini dalam Perspektif Islam, Musawa: Journal For Gender Studies, Vol 11(01) 2019, 133.
} 
37 | MUSAWA, Vol. 13 No.1 Juni 2021 : 20-43

Terjemahnya :

Hai orang-orang yang beriman, bertakwalah kepada Allah sebenar-benar takwa kepada-Nya; dan janganlah sekali-kali kamu mati melainkan dalam keadaan beragama Islam. ${ }^{29}$

Mati dalam keadaan berserah diri kepada Allah swt. sebagai muslim yang merupakan ujung dari takwa, dan sebagai akhir dari proses hidup jelas berisi kegiatan pendidikan. Dalam perspektif pendidikan Islam, kepribadian muslim memiliki seperangkat potensi, disposisi, dan karakter unik. Potensi itu paling tidak mencakup keimanan, ketauhidan, keikhlasan, kesucian, kenderungan menerima kebenaran dan kebaikan, serta sifat-sifat lainnya yang dengannya menjadikan kepribadian muslim terwujud dalam insan kamil. Sifatsifat seperti ini, terkandung sifat malaikat yang tercerminkan dalam kerinduan spiritualnya untuk mengenal Allah, lalu beriman dan bertakwa kepada-Nya.

Dari pemaparan di atas, menunjukkan bahwa peluang pendidikan Islam memiliki andil yang sangat penting dalam usaha pembentukan kepribadian anak dengan bingkai kepribadian muslim, dan dalam hal ini pula, diharapkan pembentukan kepribadian anak muslim diupayakan melalui proses pendidikan Islam dan atau pengajaran PAI di sekolah, terutama di sekolah dasar.

\section{B. Indikator Kepribadian Anak yang Ideal dalam Perspektif Pendidikan Islam}

Kepribadian anak yang ideal dalam perspektif pendidikan Islam, adalah kepribadian anak yang sifat dan sikap atau tingkah lakunya berdasarkan ajaran Islam, yang disebut dengan kepribadian muslim. Dalam pandangan Jalaluddin dan Usman Said bahwa ada dua sisi penting dalam kepribadian muslim, yakni iman dan akhlak. Iman seseorang berkaitan dengan akhlaknya. Iman sebagai konsep dan akhlak adalah implikasi dari konsep itu dalam hubungannya dengan sifat dan

\footnotetext{
${ }^{29}$ Departemen Agama RI, Al-Qur'an dan Terjemahnya (Jakarta: Proyek Pengadaan Kitab Suci Al-Qur'an, 1992), 92
} 
Bahar, Dampak Pendidikan Agama Islam ... | 38

sikap perilaku sehari-hari. ${ }^{30}$ Demikian pula jika kembali diperhatikan tujuan pendidikan Islam sebagaimana yang telah disebutkan sebelumnya, ternyata masalah iman-taqwa, dan akhlak menjadi penekanan utama. Dengan rumusan seperti ini, maka dipahami bahwa indikator utama kepribadian anak yang ideal dalam perspektif pendidikan Islam adalah, iman dan akhlaknya.

Kepribadian seorang anak yang beriman dan beraklak, juga memiliki indikator dan ciri khas dan tertentu. Dari segi artinya, iman adalah percaya "percaya" atau "yakin", dan menurut istilah adalah keyakinan dan kepercayaan yang kuat tentang keberadaan Allah swt. terutama keesan-Nya dan kekuasaanNya serta mengakui kerasulan Nabi Muhammad. Selain itu, iman adalah keyakinan dan kepercayaan dalam, diucapkan dengan lisan, dan diamalkan dengan perbuatan. Jadi mukmin, adalah orang membenarkan dan menyakini setulusnya tiada Tuhan selain Allah, mengamalkan ajarannya, kemudian tercurahnya ganjaran (pahala) kepada mereka. ${ }^{31}$ Dari sini kemudian dipahami bahwa kepribadian seoranng anak yang beriman ternyata tidak sekedar percaya kepada Allah, tetapi mencakup pula pengertian yang benar siapa Allah dan cara bersikap kepada-Nya. Dengan demikian indikator kepribadian ideal bagi seorang anak adalah pada amalnya dalam bentuk ritus (ibadah) dan aktualisasinya dalam bentuk amal shaleh yang pada gilirannya membentuk kepribadian anak yang berakhlak mulia. Dari sini, kemudian Jalaluddin dan Usman Said merumuskan bahwa indikator kepribadian tersebut, adalah :

1. Selalu menempuh jalan hidup yang didasarkan didikan ketuhanan dengan melaksanakan ibadah dalam arti luas.

\footnotetext{
${ }^{30}$ Jalaluddin dan Usman Said, Filsafat Pendidikan Islam; Konsep dan Per-kembangan Pemikirannya (Cet. II; Jakarta: PT. RajaGrafindo Persada, 1996), 94

${ }^{31}$ M. Quraish Shihab, Menyingkap Tabir Ilahi; Asma al-Husna Perspektif al-Qur'an (Cet. II; Jakarta: Lentera Hati, 1999), 49.
} 
39 | MUSA WA, Vol. 13 No.1 Juni 2021 : 20-43

2. Senantiasa berpedoman kepada petunjuk Allah untuk memperoleh bashirah dan furqan (kemampuan membedakan yang baik dan yang buruk)

3. Merasa memperoleh kekuatan untuk menyerukan dan berbuat benar, dan selalu menyampaikan kebenaran kepada orang lain.

4. Memiliki keteguhan hati untuk berpegang kepada agamanya.

5. Memiliki kemampuan yang kuat dan tegas dalam menghadapi kebatilan.

6. Tetap tabah dalam kebenaran dalam segala kondisi.

7. Memiliki kelapangan dan kententaraman hati serta kepuasan batin, sehingga sabar menerima cobaan.

8. Mengetahui tujuan hidup dan menjadikan akhirat sebagai tujuan akhir yang lebih baik.

9. Kembali kepada kebenaran dengan melakukan tobat dari segala kesalahan yang pernah diperbuat sebelumnya. ${ }^{32}$

Jadi indikator umum kepribadian seorang anak yang ideal, adalah senantiasa memperhatikan tingkah lakunya dalam beribadah, tingkah tradisi, tingkah laku yang merusak, dan tingkah laku yang menyelamatkan. Tingkah laku dalam beribadah, misalnya melaksankan shalat secara sempurnah baik rukun dan syaratnya, melakukan zikir dan membaca wirid setelah shalat, juga dengan melengkapi shalat sunnat rawatibnya. Tingkah laku tradisi, misalnya dalam etika makan didahului dengan baca doa, makan dengan tangan kanan, etika bergaul dan bersahabat, etika bepergian, dan lain-lain. Tingkah laku yang merusak, misalnya menghindarkan diri dari bahaya syahwat, bahaya harta dan pelit, angkuh dan pamer, sombong, membanggakan diri, menipun, dan selainnya. Tingkah laku yang menyelematkan, misalnya selalu mawas diri dan instropeksi diri, tafakkur dan selainnya.

${ }^{32}$ Jalaluddin dan Said, Filsafat, 96-97. 
Bahar, Dampak Pendidikan Agama Islam ... | 40

Dapat dipahami bahwa semua tingkah laku dan perbuatan baik, adalah moralitas Islami yang merupakan indikator kepribadian muslim yang sempurna.

Dalam hadis dinyatakan:

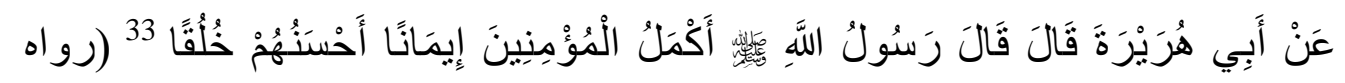
أبو داود)

Artinya :

Dari Abu Huraerah beliau berkata bahwa Rasulullah Saw. bersabda: orang mukmin yang paling sempurna imannya ialah yang terbaik akhlaknya.

Hadis di atas sekaligus menunjukan bahwa walau seseorang telah berkepribadian mukmin, namun tidak menghiasi dirinya dengan moralitas islami, maka belum sempurnalah kepribadiannya, ia belum menjadi sosok insan kamil dalam arti ia belum berkepribadian muslim yang sempurna. Dengan demikian, termasuk kepribadian anak yang ideal adalah bila anak tersebut senantiasa menjaga nilai-nilai imannya, dan menghiasi dirinya denan akhlak al-karimah.

Nilai-nilai iman pada seorang anak dalam konsep Islam, sesungguhnya telah ada pada dirinya sejak ia dilahirkan sebagai manusia yang memiliki fitrah keagamaan, dan terus dibina. Pembinaan pertama, adalah memperdengarkan kalimat iman itu sendiri melalui azan di telinganya, kemudian pada usia-usia selanjutnya, terutama ketika telah berumur tujuh tahun, anak-anak dididik secara islami yakni melaksanakan shalat, dan jika telah terbiasa shalat dalam

${ }^{33}$ Abū Dāwud Sulaimān bin al-Asy’asy al-Sijistāni, Sunan Abū Dawud, juz II (Sūriah: Dār al-H $\square$ adīśs, t.th), h. 537. 
41 | MUSAWA, Vol. 13 No.1 Juni 2021 : 20-43

umur sepuluh tahun berarti pada dirinya telah terwujud salah satu indikator kepribadian anak yang ideal dalam perspektif pendidikan Islam.

Nilai-nilai keimanan yang telah tertanam dalam diri seorang anak, hendaknya sejalan dengan nilai-nilai akhlak. Misalnya, disamping anak tersebut tekun beribadah (shalat lima waktu), hendaknya juga ia harus memperlihatkan perilaku yang baik terhadap sesamanya, gurunya, orangtuanya, dan masyarakat sekitar. Perilaku yang baik tersebut misalnya, sopan dalam berbicara, selalu membantu teman, berpakaian rapih, dan semacamnya. Kesemuanya ini, adalah indikator-indikator seorang anak yang berkepribadian ideal.

\section{KESIMPULAN}

Betapa pentingnya pendidikan agama untuk anak kita, dan betapa pula besarnya bahaya yang terjadi akibat kurangnya pendidikan agama itu. Untuk itu, perlu kiranya kita mencari jalan yang dapat mengantar kita kepada terjaminya karakter anak-anak yang kita harapkan menjadi warga Negara yang cinta akan bangsanya, dapat menciptakan dan memelihara ketentraman dan kebahagiaan masyarakat dan bangsa di kemudian hari.

Dengan demikian, pendidikan agama dalam pembentukan kepribadian mempunyai visi senantiasa mengarahkan diri pada pembentukan individu yang bermoral, cakap mengambil keputusan yang tampil dalam perilakunya, sekaligus mampu berperan aktif dalam membangun kehidupan bersama dalam tantangan global. 


\section{DAFTAR PUSTAKA}

Achmad. Ideologi Pendidikan Islam; Paradigma Humanisme Teosentris. Cet.I; Yogyakarta: Pustaka Pelajar, 2005.

Ahmadi, Abu dan Nur Uhbiyati, Ilmu Pendidikan. Cet. I; Jakarta: Rineka cipta, 1991.

Budiman, M. Nasir. Pendidikan dalam Perspektif Al-Qur'an. Cet.I; JakartaL Madani Press, 2001.

Daradjat, Zakiah et. all, Ilmu Pendidikan Islam. Cet. III; Jakarta: Bumi Aksara, 1992.

Departemen Agama RI, Al-Qur'an dan Terjemahnya. Jakarta: Proyek Pengadaan Kitab Suci Al-Qur'an, 1992.

Jalaluddin dan Usman Said, Filsafat Pendidikan Islam; Konsep dan Perkembangan Pemikirannya. Cet. II; Jakarta: PT. RajaGrafindo Persada, 1996.

Kahar, M. Iksan. Pendidikan Karakter pada Anak Usia Dini dalam Perspektif Islam, Musawa: Journal For Gender Studies, Vol 11(01) 2019.

Mappanganro, Impelementasi Pendidikan Islam di Sekolah. Cet. I; Ujung Pandang: Ahkam, 1996.

Marimba, Ahmad D. Pengantar Filsafat Pendidikan Islam. Cet. VIII: Bandung: PT. Al-Ma'arif, 1989.

Mudyahardjo, Redja. Pengantar Pendidikan; Sebuah Studi Awal tentang Dasar-dasar Pendidikan pada Umumnya dan Pendidikan di Indonesia. Cet. II; Jakarta: PT. RajaGrafindo Persada, 2002.

Mujib, Abdul. Fitrah dan Kepribadian Islam; Sebuah Pendekatan Psikologis. Cet.I; Jakarta: Darul Falah, 1999.

Al-Naisabūri, Imām Ibn H $\square$ usain Muslim bin H $\square$ ajjāj Ibn Muslim al-Qusyairi. al-Jāmi $S \square a h \square \bar{\imath} h \square$, Juz VI. Bairut: Dār al-Ma'ārif, t.th. 
43 | MUSAWA, Vol. 13 No.1 Juni 2021 : 20-43

Rama, Bahaking. Sejarah Pendidikan Islam: Pertumbuhan dan Perkembangan Hingga Masa Khulafaurrasyidin. Jakarta: Paradotama Wiragemilang, 2002.

Ramayulis, Ilmu Pendidikan Islam. Cet. I; Jakarta: Kalam Mulia, 1994

Republik Indonesia, Undang-undang RI No. 20 tahun 2003 tentang Sistem Pendidikan Nasional. Cet. I; Bandung: Fokusmedia, 2003.

Sarwono, Sarlito Wirawan. Pengantar Umum Psikologi. Cet. VI; Jakarta: Bulan Bintang, 1991.

Shihab, M. Quraish. Menyingkap Tabir Ilahi; Asma al-Husna Perspektif alQur'an. Cet. II; Jakarta: Lentera Hati, 1999.

Al-Sijistāni, Abū Dāwud Sulaimān bin al-Asy’asy. Sunan Abū Dawud, juz II. Sūriah: Dār al-H $\square$ adīś, t.th.

Sujanto, Agus et all. Psikologi Kepribadian. Cet. VII; Jakarta: Bumi Aksara, 1997

Suryabrata, Sumadi. Psikologi Perkembangan. Yogyakarta: Rake Press, 1984.

Syam, Mohammad Nur. Filsafat Pendidikan. Surabaya: Usaha Nasional, 1986.

Al-Taumiy al-Syabāni, 'Umar Muh $\square$ ammad. Falsafat al-Tarbiyat al-Islāmiyah, diterjemahkan oleh Hasan Langgulung dengan judul Falsafah Pendidikan Islam. Cet. I; Jakarta: Bulan Bintang, 1979.

Tirharahardja, Umar dan La Sula, Pengantar Pendidikan. Cet. II; Jakarta: Rineka Cipta, 1996. 